IOS Press

\title{
Differences in the carotenoid profile of commercially available organic and conventional tomato-based products
}

\author{
Anna Vallverdú-Queralt ${ }^{\mathrm{a}, \mathrm{b}}$, Miriam Martínez-Huélamo ${ }^{\mathrm{a}, \mathrm{b}}$, Isidre Casals-Ribes ${ }^{\mathrm{c}}$ \\ and Rosa M. Lamuela-Raventós ${ }^{\mathrm{a}, \mathrm{b}, *}$ \\ ${ }^{a}$ Nutrition and Food Science Department, XaRTA, INSA. Pharmacy School, University of Barcelona, Barcelona, \\ Spain \\ ${ }^{\mathrm{b}}$ CIBER CB06/03 Fisiopatología de la Obesidad y la Nutrición, (CIBEROBN). Instituto de Salud Carlos III, Spain \\ ${ }^{\mathrm{c} S}$ Scientific and Technical Services, University of Barcelona, Barcelona, Spain
}

Received 6 September 2013; accepted 22 October 2013

\begin{abstract}
.
BACKGROUND: Carotenoids are important antioxidant compounds in the human diet. Due to their constrained polyene structure, carotenoids can exist in cis and trans isomeric form. In ketchups and tomato juices, all-trans isomeric forms are predominant. OBJECTIVE: The aim of this study was to compare the carotenoid content and lipophilic antioxidant capacity of organic and conventional tomato-based products (tomato juices and ketchups) available on the market.

METHODS: Liquid chromatography coupled to mass spectrometry in tandem mode (LC-MS/MS) and HPLC-UV were used for the identification and quantification of individual carotenoids.

RESULTS: A comparative analysis of ketchups and tomato juices produced by conventional and organic systems showed statistically higher levels $(P<0.05)$ of carotenoid compounds in the organic products.

CONCLUSIONS: In this paper, differences in the carotenoid content of organic and conventional tomato juices and ketchups, previously unreported, are described.
\end{abstract}

Keywords: Carotenoids, ketchups, tomato juices, conventional food, organic food

\section{Introduction}

The demand for organically grown vegetables, including tomatoes, is increasing annually, since organic agriculture avoids the use of mineral soluble fertilizers and synthetic pesticides. In previous works made with market tomatobased products, organic ketchups and tomato juices had a significant higher phenolic content than conventional alternatives [1-3]. However little is known about the effect of organic agriculture in the levels of carotenoids on tomato. Fundamental differences between organic and conventional production systems, particularly in soil fertility management, may affect the nutritive composition of plants, including secondary plant metabolites (2-3). The synthesis of secondary plant metabolites, proteins and soluble solids are influenced by inorganic nitrogen availability.

Carotenoids exist in a wide variety of plants, including various fruits and vegetables, and in lower amounts in biological fluids and certain animal tissues. It is well known that tomatoes are the main dietary source of lycopene. In

*Corresponding author: Rosa M. Lamuela-Raventós, Nutrition and Food Science Department, XaRTA, INSA Pharmacy School, University of Barcelona, Av. Joan XXIII s/n, 08028 Barcelona, Spain. Tel.: +34 934034843; Fax: +34 934035931; E-mail: lamuela@ub.edu. 
tomatoes and tomato-based products, all-trans isomeric forms of carotenoids are predominant, although cis isomers are formed during thermal processing. In the human body, more than $50 \%$ of carotenoids have the cis isomeric conformation, which leads to the hypothesis that the cis form is more bioavailable [4]. During industrial thermal treatment of tomato matrices, lycopene is quite thermally stable [5,6], but it may suffer degradation during lengthy processing at high temperatures [7-9]. However, to date no clear evidence has been provided for the effect of organic and conventional production systems on carotenoid levels of tomato-based products. The literature also has only limited data for the individual and/or total lycopene content or antioxidant capacity of commercial tomato juices and ketchups.

We carried out a study to identify differences in the carotenoid profile of conventional and organic tomato juices and ketchups. Total carotenoid content (TC), lipophilic antioxidant capacity and the content of individual carotenoids (lutein, $\alpha$-carotene, $\beta$-carotene, trans-lycopene, 5-, 9- and 13-cis-lycopene) were determined in conventional and organic tomato juices and ketchups by HPLC-MS/MS and HPLC-UV. A $\mathrm{C}_{30}$ stationary column was used, as it gives dramatically improved resolution and selectivity of carotenoids and their isomers $[10,11]$.

\section{Materials and methods}

\subsection{Standards and reagents}

All samples and standards (99\% purity) were handled without exposure to light. $\beta$-carotene, $\alpha$-carotene, lycopene, $\beta$-apo-8'-caortenal and lutein, methyl tert-butyl ether (MTBE) and hexane were purchased from Sigma ${ }^{\circledR}$ (St. Louis, MO, USA); ethanol and methanol HPLC grade were obtained from Scharlau (Barcelona, Spain), hexane from Extrasynthèse (Genay, France) and ultrapure water (Milli-Q) from Millipore (Bedford, USA).

\subsection{Processing conditions of organic and conventional tomato juices and ketchups}

Three independent production events spread over 2010 were collected. In each event, a total of 20 tomato-based products (10 ketchups and 10 tomato juices) were analyzed. The tomato-based products analyzed were commercial tomato juices and ketchups that were available in Barcelona markets.

\subsubsection{Ketchup}

Ketchup is a sweet-and-sour condiment typical of the American diet. The technological process to obtain ketchup consists of mixing tomato paste $\left(65 \%, 30-32^{\circ}\right.$ Brix $)$ with sugar, wine vinegar, salt, aroma, and preservatives in traces. The mixture is pasteurized at $96^{\circ} \mathrm{C}$ for $4-6 \mathrm{~min}$ and packaged in bottles. The temperature must be carefully regulated to insure absorption of the ingredients without overcooking. The entire process of ketchup manufacturing generally takes between two to three hours [12].

\subsubsection{Tomato juice}

Juice is an intermediate product in the processing of tomato paste, obtained in the juice extraction stage of a process that eventually results in tomato concentrate. Tomato juice can be separated from the pulp by filtering, but more commonly the entire pulp is used as juice. The juice is formulated according to the characteristics demanded by the market: the most common is juice with extra virgin olive oil, salt, and citric juice to adjust the $\mathrm{pH}$. The product is then bottled and usually pasteurized $\left(80^{\circ} \mathrm{C}, 20 \mathrm{~min}\right)$ to extend its shelf life $[12,13]$.

\subsection{Extraction and isolation of carotenoid compounds}

\subsubsection{Extraction of carotenoids}

The extraction of carotenoids must be carried out very quickly, avoiding exposure to light, oxygen, high temperatures and also pro-oxidant metals, such as iron or copper, in order to minimize autoxidation and cis-trans isomerization according to a previously described method Vallverdú-Queralt et al. [14] with minor modifications. 
Lyophilized ketchups and tomato juices $(0.2 \mathrm{~g})$ were weighed and homogenized in duplicate with $5 \mathrm{~mL}$ EtOH: Hexane $(4: 3 \mathrm{v} / \mathrm{v})$; the homogenate was sonicated for $5 \mathrm{~min}$ and centrifuged $\left(4000 \mathrm{rpm}\right.$ at $\left.4{ }^{\circ} \mathrm{C}\right)$ for 15 minutes. The supernatant was transferred into a flask and the extraction was repeated. Both supernatants were combined and evaporated under nitrogen flow. Finally, the residue was reconstituted with up to $1 \mathrm{~mL}$ of MTBE and filtered through a $25 \mathrm{~mm}, 0.45 \mu \mathrm{m}$ PTFE filter into an amber vial for HPLC analysis.

\subsubsection{Analysis of carotenoids}

Liquid chromatography was performed with an Agilent series 1100 HPLC instrument (Agilent, Waldbronn, Germany) equipped with a quaternary pump, an autosampler, a diode array detector (DAD) and a column oven set to $30^{\circ} \mathrm{C}$. The analytes were separated on a $\mathrm{C}_{30}$ column $250 \times 4.6 \mathrm{~mm}$ i.d, $5 \mu \mathrm{m}$ (YMC ${ }^{\mathrm{TM}}$, Waters Co., Milford, MA, USA) and kept at $20^{\circ} \mathrm{C}$. The injection volume was $20 \mu \mathrm{L}$ and flow rate $1 \mathrm{~mL} / \mathrm{min}$. Mobile phases consisted of water (A), methanol (B) and MTBE (C). Separation was carried out in 23 min under the following conditions: 0 min, $70 \%$ B; $10 \mathrm{~min}, 20 \% \mathrm{~B} ; 20 \mathrm{~min}, 6 \% \mathrm{~B} ; 21 \mathrm{~min}, 6 \% \mathrm{~B} ; 23 \mathrm{~min}, 70 \% \mathrm{~B}$. Water was kept constant at $4 \%$ throughout the analysis. The column was equilibrated for $10 \mathrm{~min}$ prior to each analysis. The analysis was carried out following the procedure of other authors $[10,14]$. MTBE was used as a modifier to facilitate elution of lycopene, which is strongly retained in a methanol environment.

Commercially available carotenoid standards (lutein, $\alpha$-carotene, $\beta$-carotene, trans-lycopene and trans- $\beta$-apo- 8 'carotenal) were used to identify analytes by retention times. The UV-DAD spectra was recorded in the range of $350-550 \mathrm{~nm}$ for the tentative identification of carotenoids and their geometrical isomers on the basis of the retention times and absorption spectrum characteristics described in the literature [15].

An API 3000 (PE Sciex, Concord, Ontario, Canada) triple quadrupole mass spectrometer in positive-ion mode was used to obtain MS/MS data for carotenoid analysis. Turbo Ionspray source settings were as follows: capillary voltage, $4500 \mathrm{~V}$; nebulizer gas $\left(\mathrm{N}_{2}\right), 10$ a.u. (arbitrary units); curtain gas $\left(\mathrm{N}_{2}\right), 12$ a.u.; collision gas $\left(\mathrm{N}_{2}\right)$, 4 a.u.; focusing potential, $200 \mathrm{~V}$; entrance potential, $10 \mathrm{~V}$; drying gas $\left(\mathrm{N}_{2}\right)$, heated to $400^{\circ} \mathrm{C}$ and introduced to a flow rate of 6000 $\mathrm{cm}^{3} / \mathrm{min}$. The declustering potential and collision energy were optimized for each compound in infusion experiments. A solvent delivery system connected post-column was used for the delivery of $100 \mu \mathrm{L} / \mathrm{min}$ of a $\mathrm{LiCl}$ solution at a concentration of $500 \mathrm{ppm}$. For quantification purposes, data was collected in the multiple reaction monitoring (MRM) mode, tracking the transition of parent and product ions specific for each compound.

Quantification of carotenoids was performed by the internal standard method. The internal standard was trans$\beta$-apo-8'-carotenal. Carotenoids were quantified related to their corresponding standard and results were expressed as $\mu \mathrm{g} / \mathrm{g}$ dry weight (DW). When standards were not available, as in the case of 5-, 9- and 13-cis-lycopene, the quantification was related to the trans-lycopene. The TC content was obtained by the sum of each individual carotenoid.

\subsection{Lipophilic antioxidant capacity}

The lipophilic antioxidant capacity in ketchup and gazpacho extracts was measured using an $\mathrm{ABTS}^{+}$radical decolorization assay and DDPH assay following the procedure of Vallverdú-Queralt et al. [16] with minor modifications.

2.4.1. ABTS $^{+}$assay

$1 \mathrm{mmol} / \mathrm{L}$ Trolox (antioxidant standard) was prepared in methanol once a week. Working standards were prepared daily by diluting $1 \mathrm{mmol} / \mathrm{L}$ Trolox with methanol.

An ABTS $^{+}$radical cation was prepared by passing a $5 \mathrm{mmol} / \mathrm{L}$ aqueous stock solution of ABTS (in methanol) through manganese dioxide powder. Excess manganese dioxide was filtered through a $25 \mathrm{~mm} 0.45 \mu \mathrm{m}$ PTFE filter. Before analysis, the solution was diluted in methanol to give an absorbance at $734 \mathrm{~nm}$ of $1.0 \pm 0.1$, and pre-incubated in ice. Then, $250 \mu \mathrm{L}$ of $\mathrm{ABTS}^{+}$solution was added to $5 \mu \mathrm{L}$ of Trolox or to tomato juice and ketchup extracts and the solutions were stirred for $60 \mathrm{~s}$. The absorbance was recorded continuously every $30 \mathrm{~s}$ with a UV/VIS Thermo Multiskan Spectrum spectrophotometer for $1 \mathrm{~h}$, and methanol blanks were run in each assay.

The working range for Trolox (final concentration 0-1000 $\mathrm{mmol} / \mathrm{L}$ ) was based on triplicate determinations and consisted of plotting the absorbance as a percentage of the absorbance of the uninhibited radical cation (blank). The activities of tomato juice and ketchup extracts were assessed at four different concentrations, which were within 
the range of the dose-response curve. Each sample was analyzed in triplicate at each concentration. Results were expressed as mmol Trolox equivalent (TE)/kg DW.

\subsubsection{DPPH assay}

The antioxidant capacity was also studied by evaluating free radical-scavenging effects on the DPPH radical. Solutions of known Trolox concentration were used for calibration. $5 \mu \mathrm{L}$ of Trolox or tomato juice and ketchup extracts were mixed with $250 \mu \mathrm{L}$ of methanolic DPPH $(0.025 \mathrm{~g} / \mathrm{L})$. The homogenate was shaken vigorously and kept in darkness for $30 \mathrm{~min}$. Absorption of the samples was measured at $515 \mathrm{~nm}$. The percentage of inhibition of the DPPH was calculated and plotted as a function of the concentration of Trolox for the standard reference data. The final DPPH values were calculated using a regression equation between the Trolox concentration and the percentage of DPPH inhibition, and results were expressed as mmol TE/kg DW.

\subsection{Statistical analysis}

The significance of the results was analyzed using the Statgraphics Plus v.5.1 Windows Package (Statistical Graphics Co., Rockville, MD). Analysis of variance (ANOVA) was used to compare the means of groups of measurement data. Relationships between variables were examined using Pearson correlation coefficients. $P$ values of $<0.05$ were considered statistically significant. Principal component analysis (PCA) was carried out to obtain correlations amongst variables. PCA allows us to visualize the original arrangement of tomato juices and ketchups in an n-dimensional space by identifying the directions in which most of the information is retained.

\section{Results and discussion}

It is well known that the biosynthesis of phenolic compounds in plants is strongly influenced by the cultivar [17] and mode of fertilization [1, 18]. Vallverdú-Queralt et al. [17] suggested that organic tomatoes and tomato-based products contained higher amount of phenolic compounds than conventional alternatives. When plants are grown with artificial nutrients, they are supposed to lose their natural defense mechanisms. This may result in reduced disease resistance and diluted contents of minerals, vitamins and defense-related secondary metabolites, which are considered beneficial for human health. However, there is little information on how organic production methods affect the carotenoid content of tomato-based products. Organic fertilization has been found to yield higher $\beta$-carotene and vitamin $B_{1}$ contents in carrots [19]. Our results are in line with this study, since organic tomato juices and ketchups showed significantly $(P<0.05)$ higher levels of carotenoids than their conventional counterparts. However, other studies have shown no difference in lycopene content when comparing the effect of the cultivation system [20]. The level of carbon-based secondary metabolites is usually higher in organic plants [21, 22], due to their defensive role in plants under stress conditions [23]. With the exception of wheat, oats, and wine, organic foods typically provide greater levels of a number of important antioxidant phytochemicals (anthocyanins, flavonoids and carotenoids) [24]. Moreover, a prospective observational study by Giovannucci et al. [25], the Health Professionals Follow-Up Study, collected food frequency questionnaire data from a group of 47,365 men in 1986, 1990, and 1994, and intake of $\geq 2$ servings of tomato sauce per week was associated with a reduced risk of prostate cancer [relative risk $(\mathrm{RR})=0.77$ relative to $<1$ serving of tomato sauce per month, $P$ trend $<0.001]$. Therefore, consuming tomato-based products with a high level of carotenoids may help in the prevention of chronic diseases.

\subsection{Carotenoid profile of organic and conventional tomato-based products}

Two PCA were carried out to discriminate among organic and conventional tomato juices (Fig. 1) and ketchups (Fig. 2) according to their carotenoid profiles. The two principal components (PC1 and PC2) obtained for each tomato-based product accounted for $89.32 \%$ and $78.71 \%$ of the variability of the original data for tomato juices and ketchups, respectively. The nearer the variable Y (=loading) is located to the axis origin, the lower the contribution to the class distinction among treatments. Thus, plant metabolites, such as $\alpha$-carotene in tomato juices and lutein in ketchups, may not contribute to such discrimination between conventional and organic practices (Figs. 1 and 2). 


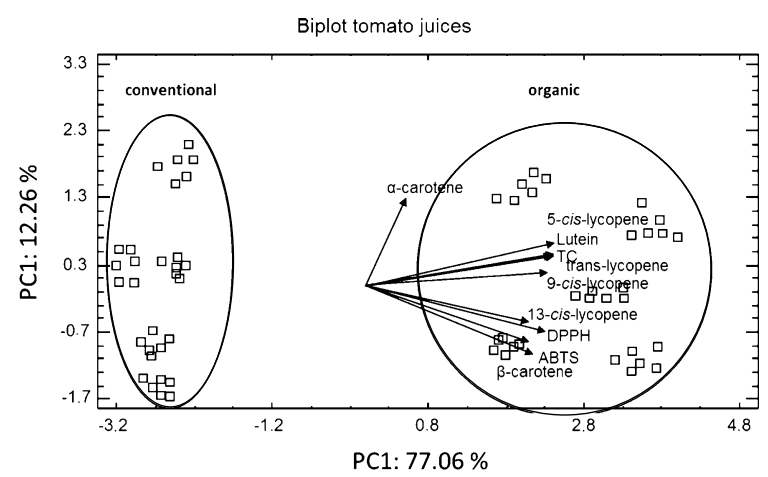

Fig. 1. Biplot of samples representing the carotenoid profile of organic and conventional tomato juices.

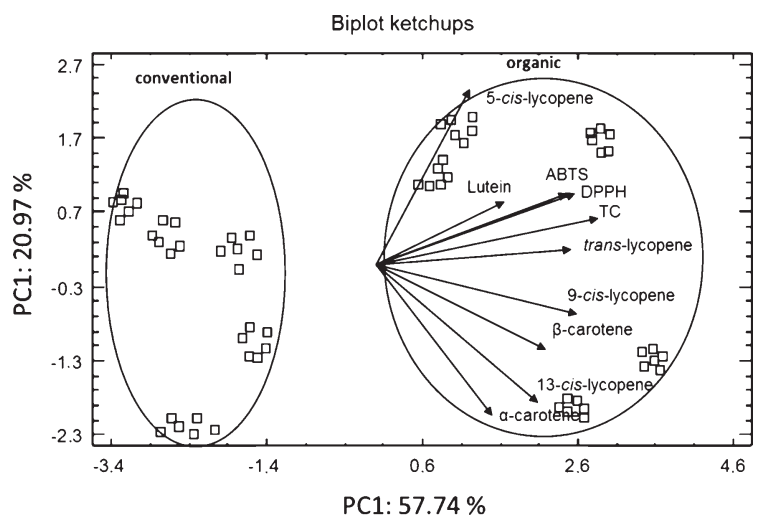

Fig. 2. Biplot of samples representing the carotenoid profile of organic and conventional ketchups.

On the other hand, large loadings for variables such as trans-lycopene and cis-lycopene isomers, $\beta$-carotene and antioxidant capacities had a high discriminating power. Changes in TC content of tomato-based products were mainly attributed to changes in some individual compounds. It can be observed that the TC content was highly correlated with individual carotenoid compounds, such as trans-lycopene, 5- and 9-cis-lycopene and lutein (Figs. 1 and 2). PCA1 was able to explain the variable differentiation between organic and conventional tomato juices and ketchups. It can be clearly observed that certain individual carotenoids strongly characterize or are highly correlated with a specific treatment. The group of organic juices and ketchups is situated on the right-hand side of the plot, and is highly correlated with trans-lycopene and cis-lycopene isomers and $\beta$-carotene. In contrast, the group of conventional juices and ketchups is situated on the left-hand side of the plot and is related to low levels of these metabolites (Figs. 1 and 2). Organic cultivation may promote the synthesis of carotenoids in organic tomato-based products. Such a metabolite production could be induced as a stress response, initiated when the plant recognizes a stimulus at the cellular level, such as a lack of nutrients, as in the case of organic cultivation, which may be accompanied by a burst of ethylene [26]. Ethylene production, which leads to lycopene biosynthesis in tomatoes, is also known to be rapidly increased by stress, e.g. a pathogenic attack or elevated salinity [26, 27]. Thus, it is possible that organic cultivation promoted ethylene production, and activated enzymes involved in lycopene biosynthesis, such as carotenoid isomerase or $\zeta$-carotene desaturase [28].

\subsection{Analysis of total carotenoid content and lipophilic antioxidant capacity}

Results are expressed as DW content of phytochemicals to minimize the effect of fertilization mode on the composition of tomato-based products (Table 1). The results showed that organic tomato juices and ketchups contained 
Table 1

Lipophilic antioxidant capacity through $\mathrm{ABTS}^{+}$and DPPH (mmol TE kg $\left.{ }^{-1} \mathrm{DW}\right)$ assays expressed as mean $\pm \mathrm{SD}$ of tomato juices and ketchups $(n=6)$; different letters in the columns represent statistically significant differences $(P<0.05)$

\begin{tabular}{|c|c|c|}
\hline Tomato-based products & $\mathrm{ABTS}^{+}$ & DPPH \\
\hline \multicolumn{3}{|l|}{ Organic Tomato juices } \\
\hline A & $26.40 \pm 1.45^{\mathrm{a}}$ & $27.80 \pm 1.49^{\mathrm{a}}$ \\
\hline B & $25.50 \pm 1.29^{\mathrm{b}}$ & $28.33 \pm 1.68^{b}$ \\
\hline $\mathrm{C}$ & $26.80 \pm 2.06^{\mathrm{a}}$ & $28.49 \pm 1.54^{b}$ \\
\hline $\mathrm{D}$ & $27.50 \pm 1.20^{c}$ & $29.30 \pm 2.02^{\mathrm{c}}$ \\
\hline $\mathrm{E}$ & $26.90 \pm 1.23^{\mathrm{a}}$ & $28.50 \pm 2.33^{b}$ \\
\hline \multicolumn{3}{|c|}{ Conventional Tomato juices } \\
\hline A & $21.30 \pm 1.03^{\mathrm{a}}$ & $24.11 \pm 1.43^{\mathrm{a}}$ \\
\hline B & $22.50 \pm 1.21^{\mathrm{b}}$ & $25.90 \pm 1.24^{b}$ \\
\hline $\mathrm{C}$ & $21.80 \pm 1.88^{\mathrm{a}, \mathrm{b}}$ & $25.30 \pm 1.03^{\mathrm{b}}$ \\
\hline $\mathrm{D}$ & $24.50 \pm 1.10^{\mathrm{c}}$ & $25.08 \pm 1.32^{\mathrm{c}}$ \\
\hline $\mathrm{E}$ & $23.10 \pm 1.03^{\mathrm{d}}$ & $25.50 \pm 1.80^{\mathrm{d}}$ \\
\hline \multicolumn{3}{|l|}{ Organic Ketchups } \\
\hline A & $33.20 \pm 1.29^{\mathrm{a}}$ & $35.50 \pm 1.26^{\mathrm{a}}$ \\
\hline B & $34.50 \pm 1.80^{\mathrm{b}}$ & $35.40 \pm 1.93^{\mathrm{a}}$ \\
\hline $\mathrm{C}$ & $33.88 \pm 1.77^{\mathrm{a}}$ & $34.80 \pm 1.03^{b}$ \\
\hline $\mathrm{D}$ & $34.30 \pm 1.80^{\mathrm{b}}$ & $36.50 \pm 1.83^{\mathrm{c}}$ \\
\hline $\mathrm{E}$ & $35.11 \pm 2.02^{\mathrm{c}}$ & $36.40 \pm 1.71^{\mathrm{c}}$ \\
\hline \multicolumn{3}{|l|}{ Conventional Ketchups } \\
\hline A & $29.59 \pm 1.73^{\mathrm{a}}$ & $29.35 \pm 1.68^{\mathrm{a}}$ \\
\hline B & $27.01 \pm 1.37^{b}$ & $28.60 \pm 1.51^{\mathrm{b}}$ \\
\hline $\mathrm{C}$ & $29.70 \pm 2.32^{\mathrm{a}}$ & $30.10 \pm 1.64^{\mathrm{c}}$ \\
\hline $\mathrm{D}$ & $28.45 \pm 1.15^{\mathrm{c}}$ & $29.14 \pm 1.62^{\mathrm{a}}$ \\
\hline $\mathrm{E}$ & $28.11 \pm 1.56^{\mathrm{c}}$ & $29.01 \pm 1.55^{\mathrm{a}}$ \\
\hline
\end{tabular}

A, B, C,D, E: different brands of each tomato based product; DW: dry weight; TE: Trolox equivalents; SD: standard deviation.

significantly $(P<0.05)$ higher concentrations of TC than their conventionally produced alternatives, being between 11 and $17 \%$ higher in the case of juices and between 17 and $18 \%$ higher in ketchups.

A similar trend was observed for lipophilic antioxidant capacity, with the lowest being determined in conventional products. It should also be noted that ketchups showed a higher lipophilic antioxidant capacity than tomato juices. However, the lipophilic antioxidant capacity per serving is much higher in tomato juice $(200 \mathrm{~mL})$ than in ketchup $(10 \mathrm{~mL})$.

Organic cultivation requires the use of environmentally-friendly chemicals to reduce harmful side-effects on consumer health. The use of natural elicitors is an alternative to conventional treatments to induce natural resistance against fungal diseases. One of the most important natural fungicides in organic farming is sulphur. Agustí-Ribas et al. compared the effects of sulphur and two elicitors (Chitoplant ${ }^{\circledR}$ and Milsana ${ }^{\circledR}$ ) on the nutritional quality of tomato. These treatments positively affected the concentrations of some phytochemicals (ascorbic acid, quercetin, trisaccharide, quercetin-3-O-rutinoside, $\beta$-carotene or potassium) in tomato fruit compared with untreated control plants [29], implying that herbicides and pesticides used in conventional agriculture may inhibit carotenoid biosynthesis in leaves. Moreover, Mercadante et al. [30] reported higher levels of all constituent carotenoids in samples collected from an organic farm than in those taken from a conventional farm using agrochemicals.

\subsection{Quantitation of individual polyphenols in conventional and organic ketchups}

Specific carotenoid compounds were monitored in conventional and organic tomato juices and ketchups, with the results shown in Table 2 and Table 3. The main carotenoid was trans-lycopene, present at levels ranging from 
Table 2

Carotenoid content $(\mu \mathrm{g} / \mathrm{g} \mathrm{DW})$ in organic and conventional tomato juices $(n=6)$. Different letters between columns represent statistical significant differences $(P<0.05)$

\begin{tabular}{|c|c|c|c|c|c|c|c|c|}
\hline $\begin{array}{l}\text { Tomato-based } \\
\text { product }\end{array}$ & Lutein & $\alpha$-carotene & $\beta$-carotene & trans-lycopene & 5-cis-lycopene & 9-cis-lycopene & 13-cis-lycopene & $\begin{array}{c}\text { Total } \\
\text { carotenoid } \\
\text { content } \\
\text { (TC) }\end{array}$ \\
\hline \multicolumn{9}{|l|}{ Organic } \\
\hline \multicolumn{9}{|l|}{ tomato juice } \\
\hline A & $1.49 \pm 0.06^{\mathrm{a}}$ & $25.23 \pm 2.10^{\mathrm{a}}$ & $249.30 \pm 20.40^{\mathrm{a}}$ & $1102.33 \pm 99.32^{\mathrm{a}}$ & $71.63 \pm 4.26^{\mathrm{a}}$ & $66.20 \pm 2.40^{\mathrm{a}}$ & $32.40 \pm 1.50^{\mathrm{a}}$ & 1548.58 \\
\hline B & $1.38 \pm 0.04^{\mathrm{b}}$ & $10.22 \pm 0.74^{\mathrm{b}}$ & $240.36 \pm 25.30^{b}$ & $1145.39 \pm 50.36^{\mathrm{b}}$ & $73.96 \pm 5.27^{\mathrm{b}}$ & $69.40 \pm 1.82^{\mathrm{b}}$ & $36.50 \pm 1.22^{\mathrm{b}}$ & 1577.21 \\
\hline $\mathrm{C}$ & $1.65 \pm 0.07^{\mathrm{c}}$ & $17.19 \pm 1.15^{\mathrm{c}}$ & $310.26 \pm 29.50^{c}$ & $1236.96 \pm 102.30^{c}$ & $78.10 \pm 4.54^{\mathrm{c}}$ & $70.30 \pm 1.66^{\mathrm{b}}$ & $35.50 \pm 1.56^{\mathrm{a}}$ & 1749.96 \\
\hline $\mathrm{D}$ & $1.46 \pm 0.08^{\mathrm{d}}$ & $11.40 \pm 1.37^{\mathrm{d}}$ & $337.40 \pm 19.20^{\mathrm{d}}$ & $1230.54 \pm 80.36^{\mathrm{c}}$ & $74.20 \pm 3.12^{\mathrm{b}}$ & $73.25 \pm 2.02^{\mathrm{c}}$ & $29.60 \pm 1.32^{\mathrm{c}}$ & 1757.85 \\
\hline $\mathrm{E}$ & $1.74 \pm 0.09^{\mathrm{e}}$ & $19.33 \pm 1.54^{\mathrm{e}}$ & $280.10 \pm 18.20^{\mathrm{e}}$ & $1340.74 \pm 91.23^{\mathrm{d}}$ & $80.20 \pm 2.66^{\mathrm{d}}$ & $73.90 \pm 2.31^{\mathrm{c}}$ & $30.05 \pm 1.48^{\mathrm{c}}$ & 1826.06 \\
\hline \multirow{2}{*}{\multicolumn{9}{|c|}{$\begin{array}{c}\text { Conventional } \\
\text { tomato juice }\end{array}$}} \\
\hline & & & & & & & & \\
\hline A & $1.02 \pm 0.04^{\mathrm{f}}$ & $22.30 \pm 2.02^{\mathrm{f}}$ & $203.20 \pm 20.40^{\mathrm{f}}$ & $920.14 \pm 56.30^{\mathrm{e}}$ & $40.20 \pm 4.23^{\mathrm{e}}$ & $60.32 \pm 3.20^{\mathrm{d}}$ & $20.36 \pm 1.25^{\mathrm{d}}$ & 1267.54 \\
\hline B & $1.01 \pm 0.02^{\mathrm{f}}$ & $8.60 \pm 0.69^{g}$ & $209.60 \pm 31.02^{\mathrm{g}}$ & $740.20 \pm 30.10^{f}$ & $33.80 \pm 2.78^{\mathrm{f}}$ & $57.40 \pm 2.54^{\mathrm{e}}$ & $26.40 \pm 1.96^{\mathrm{e}}$ & 1077.01 \\
\hline $\mathrm{C}$ & $0.99 \pm 0.05^{\mathrm{f}}$ & $15.36 \pm 1.66^{\mathrm{h}}$ & $220.30 \pm 39.05^{\mathrm{h}}$ & $810.40 \pm 70.50^{\mathrm{g}}$ & $38.30 \pm 3.60^{\mathrm{g}}$ & $51.33 \pm 2.99^{\mathrm{f}}$ & $19.75 \pm 1.02^{\mathrm{d}}$ & 1186.43 \\
\hline $\mathrm{D}$ & $0.90 \pm 0.09^{\mathrm{g}}$ & $8.10 \pm 1.66^{\mathrm{i}}$ & $230.63 \pm 15.30^{\mathrm{i}}$ & $720.10 \pm 40.89^{h}$ & $21.69 \pm 2.10^{\mathrm{h}}$ & $60.20 \pm 1.85^{\mathrm{d}}$ & $23.56 \pm 1.23^{\mathrm{f}}$ & 1125.18 \\
\hline $\mathrm{E}$ & $1.03 \pm 0.04^{\mathrm{f}}$ & $15.20 \pm 1.39^{j}$ & $220.36 \pm 20.10^{\mathrm{h}}$ & $890.32 \pm 60.29^{i}$ & $25.99 \pm 1.19^{\mathrm{i}}$ & $59.63 \pm 1.93^{\mathrm{d}}$ & $20.96 \pm 0.99^{\mathrm{g}}$ & 1233.49 \\
\hline
\end{tabular}

$810.49 \mu \mathrm{g} / \mathrm{g}$ DW to $2980.20 \mu \mathrm{g} / \mathrm{g}$ DW in ketchups, and $720.10 \mu \mathrm{g} / \mathrm{g}$ DW to $1340.74 \mu \mathrm{g} / \mathrm{g}$ DW in tomato juices. The differences between different tomato-based products could be mainly due to genotypic factors and to an enhanced enzymatic activity of phytoene synthase I, which causes a high production of lycopene precursors in ripening grade tomatoes [31]. trans-Lycopene ranged from $1525.39 \mu \mathrm{g} / \mathrm{g}$ DW to $2980.20 \mu \mathrm{g} / \mathrm{g}$ DW in organic ketchups, compared to $810.49 \mu \mathrm{g} / \mathrm{g}$ DW to $2477.91 \mu \mathrm{g} / \mathrm{g}$ DW in conventional counterparts. The same trend was observed in organic and conventional tomato juices. Our results are similar to those reported by Caris-Veyrat et al. [32], who found higher levels of lycopene in organic as opposed to conventional tomatoes.

We also analyzed the content of $c i s$-lycopene isomers in organic and conventional ketchups and tomato juices. cisIsomers are believed to have a higher antioxidant capacity [33] and to be more bioavailable [4] than trans-isomers. In vitro experiments support the conclusion that increased bioavailability of lycopene cis-isomers is at least partially due to increased micellarization and increased uptake by the enterocyte relative to trans-lycopene [34]. Therefore, human studies have been focused on the nutritional benefits of consuming tomato products with an increased percentage of cis-isomers. trans-Lycopene represents the most abundant lycopene isomer in tomato-based products but it varies from $35 \%$ to $96 \%$ of total lycopene, while 5-, 9-, 13-, and 15-cis-lycopene are the main cis-isomers detected [14].

Absolute differences in 5-cis lycopene levels were also found in organic tomato juices and ketchups compared with conventional alternatives. 5-cis-Lycopene ranged from (21.69-40.20) $\mu \mathrm{g} / \mathrm{g} \mathrm{DW}$ in conventional tomato juices to (71.63-80.20) $\mu \mathrm{g} / \mathrm{g}$ DW in organic tomato juices. In ketchups, 5-cis-lycopene levels ranged from (56.29-211.14) $\mu \mathrm{g} / \mathrm{g}$ DW in organic variants to (110.80-423.66) $\mu \mathrm{g} / \mathrm{g}$ DW in conventional alternatives. For 9- and 13-cis lycopene isomers, the differences between conventional and organic tomato juices and ketchups were not so accute as in the case of 5-cis-lycopene, although levels still tended to be higher in organic products. Levels of 9-cis-lycopene ranged from (51.33-60.32) $\mu \mathrm{g} / \mathrm{g}$ DW in conventional tomato juices to (66.20-73.90) $\mu \mathrm{g} / \mathrm{g}$ DW in organic tomato juices, whereas in ketchups levels were higher, ranging from (66.58-136.54) $\mu \mathrm{g} / \mathrm{g}$ DW in conventional products to (101.20 to 220.39$) \mu \mathrm{g} / \mathrm{g}$ DW in organic variants. 13-cis-Lycopene followed a similar trend, with higher levels found in organic tomato juices and ketchups. Similarly, Leclerc et al. [19] found a higher content of carotenoids in organically as opposed to conventionally grown carrots. Organic farming systems receive lower amounts of nutrients such as fertilizers, which could explain why organic tomatoes produce more metabolites. These differences may be linked to a different ripening period or release of the supplied nutrients [2]. Existing studies show that organic fertilization 
Table 3

Carotenoid content ( $\mu \mathrm{g} / \mathrm{g}$ DW) in organic and conventional ketchups $(n=6)$. Different letters between columns represent statistical significant differences $(P<0.05)$

\begin{tabular}{|c|c|c|c|c|c|c|c|c|}
\hline $\begin{array}{l}\text { Tomato-based } \\
\text { product }\end{array}$ & Lutein & $\alpha$-carotene & $\beta$-carotene & trans-lycopene & 5-cis-lycopene & 9-cis-lycopene & 13-cis-lycopene & $\begin{array}{c}\text { Total } \\
\text { carotenoid } \\
\text { content } \\
\text { (TC) }\end{array}$ \\
\hline \multicolumn{9}{|l|}{$\begin{array}{l}\text { Organic } \\
\text { ketchup }\end{array}$} \\
\hline A & $1.97 \pm 0.04^{\mathrm{a}}$ & $13.20 \pm 0.91^{\mathrm{a}}$ & $401.96 \pm 26.57^{\mathrm{a}}$ & $1960.23 \pm 158.12^{\mathrm{a}}$ & $201.30 \pm 9.32^{\mathrm{a}}$ & $101.20 \pm 5.83^{\mathrm{a}}$ & $51.36 \pm 2.09^{\mathrm{a}}$ & 2731.22 \\
\hline $\mathrm{B}$ & $2.10 \pm 0.08^{\mathrm{a}}$ & $35.50 \pm 2.33^{b}$ & $596.10 \pm 30.80^{\mathrm{b}}$ & $1525.39 \pm 93.18^{\mathrm{b}}$ & $110.80 \pm 5.33^{b}$ & $154.23 \pm 9.30^{\mathrm{b}}$ & $90.40 \pm 4.21^{\mathrm{b}}$ & 2514.52 \\
\hline $\mathrm{C}$ & $1.95 \pm 0.09^{\mathrm{a}}$ & $25.60 \pm 1.80^{\mathrm{c}}$ & $508.30 \pm 36.78^{c}$ & $2980.20 \pm 291.80^{c}$ & $152.99 \pm 7.20^{\mathrm{c}}$ & $220.39 \pm 5.90^{c}$ & $102.56 \pm 5.20^{\mathrm{c}}$ & 3991.99 \\
\hline $\mathrm{D}$ & $2.05 \pm 0.09^{\mathrm{a}}$ & $15.33 \pm 1.96^{\mathrm{d}}$ & $402.50 \pm 25.20^{\mathrm{a}}$ & $1856.88 \pm 101.10^{\mathrm{d}}$ & $290.64 \pm 10.20^{\mathrm{d}}$ & $101.28 \pm 4.27^{\mathrm{a}}$ & $35.33 \pm 1.25^{\mathrm{d}}$ & 2704.01 \\
\hline $\mathrm{E}$ & $2.29 \pm 0.10^{\mathrm{b}}$ & $22.39 \pm 2.01^{\mathrm{e}}$ & $512.30 \pm 25.63^{c}$ & $1840.36 \pm 93.22^{\mathrm{d}}$ & $423.66 \pm 19.37^{\mathrm{e}}$ & $179.30 \pm 8.60^{\mathrm{d}}$ & $48.70 \pm 2.99^{\mathrm{e}}$ & 3029.00 \\
\hline \multicolumn{8}{|l|}{ Conventional } & \\
\hline A & $1.43 \pm 0.03^{\mathrm{c}}$ & $10.01 \pm 0.61^{\mathrm{f}}$ & $257.89 \pm 23.37^{\mathrm{d}}$ & $1342.04 \pm 116.71^{\mathrm{e}}$ & $115.69 \pm 7.60^{\mathrm{f}}$ & $74.65 \pm 1.67^{\mathrm{e}}$ & $32.69 \pm 1.88^{\mathrm{f}}$ & 1784.39 \\
\hline $\mathrm{B}$ & $1.41 \pm 0.05^{\mathrm{c}}$ & $28.28 \pm 2.33^{\mathrm{g}}$ & $485.74 \pm 29.72^{\mathrm{e}}$ & $810.49 \pm 53.88^{f}$ & $56.29 \pm 4.43^{\mathrm{g}}$ & $85.26 \pm 8.05^{\mathrm{f}}$ & $51.80 \pm 3.39^{\mathrm{g}}$ & 1519.26 \\
\hline $\mathrm{C}$ & $1.40 \pm 0.08^{\mathrm{c}}$ & $18.49 \pm 1.06^{\mathrm{h}}$ & $315.73 \pm 34.75^{\mathrm{f}}$ & $2477.91 \pm 266.69^{\mathrm{g}}$ & $99.24 \pm 5.17^{\mathrm{h}}$ & $136.54 \pm 4.60^{\mathrm{g}}$ & $71.82 \pm 3.47^{\mathrm{h}}$ & 3121.12 \\
\hline $\mathrm{D}$ & $1.42 \pm 0.07^{\mathrm{c}}$ & $10.61 \pm 1.28^{\mathrm{i}}$ & $237.30 \pm 19.20^{\mathrm{d}}$ & $1107.32 \pm 75.89^{\mathrm{h}}$ & $180.35 \pm 9.92^{\mathrm{i}}$ & $66.58 \pm 3.67^{\mathrm{h}}$ & $20.37 \pm 0.91^{\mathrm{i}}$ & 1623.95 \\
\hline$\underline{E}$ & $1.68 \pm 0.06^{\mathrm{d}}$ & $17.08 \pm 1.16^{\mathrm{j}}$ & $382.59 \pm 23.11^{\mathrm{g}}$ & $1156.71 \pm 64.32^{\mathrm{i}}$ & $211.14 \pm 15.67^{j}$ & $105.24 \pm 9.79^{\mathrm{i}}$ & $26.47 \pm 2.48^{\mathrm{j}}$ & 1900.92 \\
\hline
\end{tabular}

practices produce crops with higher levels of ascorbic acid and lower nitrate levels compared with conventionally grown crops [35].

While lycopene is the main carotenoid in tomatoes (approximately $90-96 \%$ of TC), we also analysed the lutein, $\beta$-carotene and $\alpha$-carotene content (see Table 2 and Table 3 ). The concentrations of lutein, and $\alpha$ - and $\beta$-carotene were much lower in the conventionally produced ketchups and tomato juices. $\beta$-carotene levels in tomato juices ranged from (203.20-230.63) $\mu \mathrm{g} / \mathrm{g}$ DW in conventional tomato juices to (240.36-337.40) in organic variants. Ketchups followed the same pattern, with higher values found in organic products. Our results were similar to those of Koh et al. [36], who reported a significantly higher level of $\beta$-carotene $(P<0.05)$ in organic compared to conventional tomato sauces. Similarly, the content of $\alpha$-carotene in organic ketchups and tomato juices was $12-25 \%$ higher than in conventional alternatives. Lutein content also increased, by $35 \%$, when ketchups and tomato juices were produced organically. Therefore, carotenoid levels in tomato-based products can be said to strongly depend on the cropping system.

It is essential to consider not only the lycopene content of a processed tomato product but also its bioavailability. A study of the impact of organic and conventional agricultural systems on the carotenoid content in carrots and human diets found that the plasma status of carotenoids in humans increased significantly after the consumption of both organic and conventional crops, observing no systematic differences between the agricultural production systems [37]. However, more studies are required to study carotenoids from a standpoint of bioavailability and bioaccessibility. Lycopene bioaccessibility is a prerequisite for its bioavailability since lycopene absorption by the human body demands that lycopene is released from the physical matrix [38].

The results obtained in this study of carotenoid profiling led to the distinction of features that differentiate between organic and conventional tomato-based products. Statistical analysis was performed to identify metabolites that may serve as markers for organic and conventional ketchups and tomato juices. Organic counterparts tend to provide food with a higher content of carotenoids. Plant defense-related secondary metabolites are generally considered to be the most important determinant of the nutritional value of fruits and vegetables and thus organically grown products are more health-promoting than conventional products. This study has limitations in that more samples proceeding from a greater variety of sources should be analyzed to evaluate significant differences between organic and conventional products. Human intervention studies in vivo are also necessary to evaluate the impact of organic food on human health. 


\section{Acknowledgments}

The authors would like to express their gratitude for financial support from CICYT (AGL2010-22319-C03 and AGL2013-49083-C3-1-R) from the Spanish Ministry of Science and Innovation (MICINN), Spain. and to the CIBERobn, an initiative of the Instituto de Salud Carlos III, Spain. A. V-Q and M-M-H received support from MICINN.

\section{References}

[1] Vallverdú-Queralt A, Jáuregui O, Medina-Remon A, Lamuela-Raventos RM. Journal of Agricultural and Food Chemistry. $2012 ; 60: 3373$.

[2] Vallverdú-Queralt A, Medina-Remón A. Casals-Ribes I, Lamuela-Raventos RM. Food Chemistry. 2012;130:222.

[3] Vallverdu-Queralt A, Medina-Remon, A, Casals-Ribes I, Amat M, la Raventos RM. Journal of Agricultural and Food Chemistry. 2011.

[4] Boileau TWM, Boileau AC, Erdman JW, Exp Biol Med. 2002;227:914.

[5] Thompson KA, Marshall MR, Sims CA, Wei CI, Sargent SA, Scott JW. Journal of Food Science. 2000;65:791.

[6] Nguyen D, Francis M, Schwartz, S. J Sci Food Agric. 2001;81:910.

[7] Takeoka GR, Dao L, Flessa S, Gillespie DM, Jewell WT, Huebner B, Bertow D, Ebeler SE. Journal of Agricultural and Food Chemistry. 2001;49:3713.

[8] Shi J, Maguer ML, Bryan M, Kakuda Y. Journal of Food Process Engineering. 2003;25:485.

[9] Sharma SK, Le Maguer M, Food Research International. 2004;29:309.

[10] Matea C, Soran A, Pintea M, Bele C, Bulletin of university of agricultural sciences and veterinary medicine cluj-napoca. Agriculture. 2010;67:298.

[11] Garcia-Alonso FJ, Bravo S, Casas J, Perez-Conesa D, Jacob K, Periago MJ. Journal of Agricultural and Food Chemistry. 2009;57:6815.

[12] Galicia-Cabrera RM. Tomato processing. In Y.H. Hui. (Ed.), Hanbook of food products manufacturing, 2007, pp. 1091-1121. USA: Wiley-Interscience.

[13] Gahler S, Otto K, Bohm V. J Agric Food Chem. 2003;51:7962.

[14] Vallverdu-Queralt A, Martinez-Huelamo M, Arranz-Martinez S, Miralles E, Lamuela-Raventos RM. J Sci Food Agric. 2012;92:2043.

[15] Frohlich K, Conrad J, Schmid A, Breithaupt DE, Bohm V. International Journal for Vitamin and Nutrition Research. 2007;77:369.

[16] Vallverdú-Queralt A, Medina-Remón A, Andres-Lacueva C, Lamuela-Raventos RM. Food Chemistry. 2011;126:1700.

[17] Vallverdu-Queralt A, Medina-Remon A, Martinez-Huelamo O, Jauregui M, Andres-Lacueva C, Lamuela-Raventos RM. Journal of Agricultural and Food Chemistry. 2011;59:3994.

[18] Macheix J-J, Feuriet A, Billot J. CRC Press: Boca Raton, Florida, 1990, p. 378.

[19] Leclerc J, Miller ML, Joliet E, Rocquelin G. Biological Agriculture \& Horticulture. 1991;7:339.

[20] Juroszek P, Lumpkin HM, Yang RY, Ledesma DR, Ma CH. Journal of Agricultural and Food Chemistry. 2009;57:1188.

[21] Radi M, Mahrouza M, Jaouad A, Amiot MJ. Agronomie. 2003;23:737.

[22] Brandt K, Molgaard JP. Journal of the Science of Food and Agriculture. 2001;81:924.

[23] Dixon RA, Paiva NL. Plant Cell. 1995;7:1085.

[24] Crinnion WJ. Altern Med Rev. 2010;15:4.

[25] Giovannucci E, Rimm EB, Liu Y, Stampfer MJ, Willett WC. Journal of the National Cancer Institute. 2002;94:391.

[26] Dannehl D, Huyskens-keil S, Eichholz I, Ulrichs C, Schmidt U. 2011:157.

[27] Shibli R, Kushad M, Yousef G, Lila M. Plant Growth Regulation. 2007;51:159.

[28] DellaPenna D, Pogson BJ. Annu Rev Plant Biol. 2006;57:711.

[29] Ribas-Agustí A, Bouchagier P, Skotti E, Erba D, Casiraghi C, Sárraga C, Castellar M. The Journal of Horticultural Science \& Biotechnology. 2013;88:67.

[30] Mercadante AZ, Rodriguez-Amaya DB. Journal of Agricultural and Food Chemistry. 1991;39:1094.

[31] Fraser PD, Enfissi EMA, Bramley PM. Archives of Biochemistry and Biophysics. 2009;483:196.

[32] Caris-Veyrat C, Amiot MJ, Tyssandier V, Grasselly D, Buret M, Mikolajczak M, Guilland JC, Bouteloup-Demange C, Borel P. Journal of Agricultural and Food Chemistry. 2004;52:6503.

[33] Bohm V, Puspitasari-Nienaber NL, Ferruzzi MG, Schwartz SJ. Journal of Agricultural and Food Chemistry. 2001;50:221.

[34] Failla M, Chitchumroonchokchai C, Ishida B. J Nutr. 2008;138:482.

[35] V. Worthington, Alternative Therapies in Health and Medicine. 1998;4:58.

[36] Koh E, Wimalasiri K, Renaud E, Mitchell A. J Sci Food Agric. 2008;88:344.

[37] Soltoft M, Bysted A, Madsen KH, Mark AB, Bügel SG, Nielsen J, Knuthsen P. J Sci Food Agric. 2011;91:767.

[38] Colle IJP, Andrys A, Grundelius A, Lemmens L, L+Âfgren A, Van Buggenhout S, Van Loey A, Hendrickx M. Journal of Food Science. 2011;76:C714-C723 